DOI: $10.12775 /$ szhf.2013.012

\title{
Mirosław Żelazny, Filozofia i psychologia egzystencjalna, Wydawnictwo Naukowe UMK, Toruń 2011, ss. 564.
}

Gdybym miał podać w czterech słowach największy atut monografii Żelaznego stwierdziłbym: objaśnienie sensu pojęcia egzystencja. W języku polskim, filozoficznym, jak i potocznym, termin ten funkcjonuje niemal jak przysłowiowe abrakadabra. Oznacza coś bardzo ważnego, chciałoby się powiedzieć tak ważnego, że aż nie można powiedzieć co to jest. Jest to więc znak, któremu nie przypisuje się żadnego znaczenia, ale pominięcie go byłoby jawnym świętokradztwem. Mówimy o sensie, głębi, przeznaczeniu, ludzkiej egzystencji, o lęku egzystencjalnym itd. Czym jednak jest sama egzystencja?

W czwartym rozdziale pierwszej części pracy, zatytułowanym Ewolucja pojęcia egzystencji u Kierkegaarda, Jaspersa i Heideggera Żelazny wyjaśnia to zagadnienie. Wykazuje, że choć źródeł pojęcia egzystencji pojmowanej jako tzw. „głęboko ludzka istota” (u Heideggera nie będzie ona nawet ludzka, bo zawieszając humanizm zawiesza on pojęcie człowiek), to właściwy sens nadał owemu pojęciu dopiero Jaspers w swojej Allgemeine Psychopathologie, uznanej przez Żelaznego za pierwsze dzieło właściwej psychologii egzystencjalnej.

Viktor Frankl sens egzystencji określa zwrotem „ukryty charakter”. Chcąc ów sens przybliżyć czytelnikowi autor w pierwszej części pracy odwołuje się do przykładów zaczerpniętych z szeroko pojmowanej kultury, zwłaszcza ze znanych dzieł literackich. Za szczególnie cenną interpretację całego problemu uznaje los głównego bohatera powieści Józefa Conrada Lord Jim. Ten młody człowiek doświadczył faktu, że w obliczu nieoczekiwanej katastrofy (Jaspers nazwie takie wydarzenie sytuacją graniczną), objawia się nagle taka cecha jego charakteru, o którą się nie podejrzewał: tchórzostwo. Potem do końca życia będzie go dręczyć beznadziejne pytanie: czy „w głębi duszy” jest, czy nie jest tchórzem? Na pytanie to nie znajdzie odpowiedzi, bo całe zagadnienie nie jest teoretyczne. Jak twierdzi Żelazny, gdyby ktoś z nas został na przykład 
poddany torturom mającym na celu wydanie oprawcom własnego dziecka, jakoś by się zachował: albo by je wydał, albo nie. Predyspozycje do takiego czy innego zachowania są już zawarte w naszym ukrytym charakterze. Ale na pytanie, jakie one są nie potrafimy odpowiedzieć, dopóki konkretna sytuacja życiowa nie wydobędzie ich na światło dzienne. Sytuację taką Jaspers nazwie graniczną.

W Allgemeine Psychopathologie filozof nie używa jednak pojęcia charakter tylko egzystencja. Uważa, że słowo charakter zostało już zużyte poprzez psychologię empiryczną. Mówi się o charakterze cholerycznym, melancholijnym, sadystycznym itp., przy czym zawsze chodzi wówczas o pojęciowe uogólnienie konkretnych obserwacji naukowych dokonanych od zewnątrz. Natomiast „ukryty charakter”, czyli egzystencja Jaspersa, to niepowtarzalne i jednostkowe, ale ukryte bycie tym oto właśnie człowiekiem, nigdy do końca nieznane, a rozjaśniane tylko w sytuacjach granicznych (takich jak ta, która spotkała Lorda Jima), albo w długotrwałej międzyludzkiej komunikacji. Na określenie tak rozumianej osoby (per-son), czyli ukrytego charakteru Jaspers używa terminu egzystencja jeszcze z jednego powodu. Otóż uważa on, że to właśnie poprzez rozjaśnianie egzystencji, co Heidegger nazwie otwieraniem się na nią, uzyskaliśmy jedynie możliwość ontycznego, nie ontologicznego, otwarcia na byt (bycie, niem. Sein). Kwestia, w jaki sposób takie stanowisko Jaspersa oddziałało bezpośrednio na poglądy Heideggera omówiona została w drugiej części omawianego rozdziału Ewolucja pojęcia egzystencji u Kierkegaarda, Jaspersa i Heideggera wyłączonej z recenzowanej rozprawy i wydrukowanej w niniejszym numerze Studiów z historii filozofii. Żelazny zdecydował się na takie wyłączenie, gdyż nie chciał obciążać konstrukcji pierwszej części rozprawy, noszącej tytuł Naturalne i kulturowe źródła pytania o egzystencję, a mającej charakter eseistyczny, zbyt specjalistycznymi rozważaniami.

W części tej autor omawia odniesienia myśli egzystencjalnej zarówno do poglądów filozofów i ludzi kultury, którzy wyraźnie posługiwali się pojęciem egzystencji (Platon, Kierkegaard), jak i do takich, którzy kojarzą się z egzystencjalizmem, a w których kategoria samej egzystencji jest mniej widoczna (Pascal, Nietzsche). Żelazny dokonuje też bardzo interesującego zestawienia europejskiego pojęcia egzystencji z indyjskim pojęciem karmy. Tu chciałbym powtórzyć przytoczony na 97 stronie pracy cytat z dialogu indyjskiego filozofa Nisargadatty Makaraja: „Karma jest tylko magazynem niezużytej energii niespełnionych pragnień i niezrozumiałych obaw. Magazyn stale się napełnia nowymi pragnieniami i lękami. Ale nie musi tak być zawsze. Niech Pan spró- 
buje zrozumieć istotną przyczynę pańskich obaw (wyobcowania z samego siebie) i pragnień (tęsknoty za jaźnią) a pańska karma zniknie jak sen”.

Drugi rozdział pracy noszący tytuł Wielka trylogia filozofii egzystencji zawiera próbę systematycznego omówienia trzech sztandarowych dzieł egzystencjalizmu: Bycia i czasu Heideggera, Philosophie Jaspersa oraz Bytu i nicościSartréa. Zaraz na wstępie autor zaznacza, że celem rozdziału nie jest wyczerpujące zaprezentowanie tych dzieł, ale omówienie ich tylko w tym zakresie, w jakim dotyczą one przede wszystkim właśnie filozofii egzystencji. Żelazny nazwy egzystencjalizm w ogóle używa w sensie merytorycznym, a nie klasyfikującym przynależność do szkoły, bo chce uniknąć bezsensownych jego zdaniem sporów, czy np. Heidegger był raczej egzystencjalistą, fenomenologiem, czy też hermeneutykiem. Egzystencjalizm to dla autora recenzowanej pracy po prostu filozofia egzystencji i pisząc o kontrowersjach pomiędzy Jaspersem, Heideggerem a Sartrem, kładzie on nacisk nie tyle na deklaracje samych uczestników sporu, ile na leżące u jego podstaw zagadnienia merytoryczne.

$\mathrm{Na}$ wstępie, w części poświęconej Byciu i czasowi, Żelazny stara się uporządkować wzajemne relacje różnie przekładanych przez tłumaczy Heideggera i Jaspersa terminów Sein, Dasein, Seiende. Zgadza się, choć jakby niechętnie na to, żeby zgodnie z propozycją Krzysztofa Michalskiego, Heideggerowskie Sein przekładać jako bycie, zgodnie zaś z propozycją tłumaczy Jaspersa termin ten oddawać jako byt. Podkreśla jednak, że obu filozofom chodzi o ten sam termin, a chcąc zachować konsekwencję terminologiczną, obok polskiego bycie lub byt umieszcza zawsze $\mathrm{w}$ nawiasie oryginalne niemieckie Sein. Termin Dasein przekłada jednak jako „bycie to oto”, Seiende zaś jako „coś będącego". Podkreśla też (s. 173), że sens tego ostatniego terminu zawsze zależy od przysługującego mu rodzajnika.

Szczególnie trafnym pomysłem było wykorzystanie w celu zestawienia z dziełami Heideggera i Jaspersa z filozofią Sartre’a, autoryzowanego przekładu Bytu i nicości na język niemiecki, dokonanego w 1952 roku przez Stellera. Omawiając poglądy francuskiego myśliciela, Żelazny odwołuje się co prawda do uznanego tłumaczenia polskiego, ale narracja testu zawarta w rozdziale poświęconym Byciu i nicości poprowadzona jest tak, by dzieło to można było odczytać jako kontynuację i polemikę w stosunku do myśli Heideggera i Jaspersa.

Ostatnia część pracy poświęcona jest najbardziej dziś żywotnej części egzystencjalizmu, a mianowicie psychologii egzystencjalnej. Autor omawia tu zagadnienia psychopatologii Jaspersa (by nie popadać w rozwlekłość znów 
część tekstu wyłącza z książki, wydając go w "Studiach z Historii Filozofii”, $\mathrm{nr}$ 2), a następnie koncentruje się na nieznanych w Polsce koncepcjach Binswangera i Bossa. Bardziej pobieżnie omawia natomiast poglądy Frankla, którego wpływ na rozwój psychologii egzystencjalnej ceni bardzo wysoko. Czyni to z tego powodu, że podstawowe zręby swej psychologii egzystencjalnej austriacki lekarz i myśliciel przedstawił w popularnych, powszechnie dostępnych w języku polskim esejach, do których lektury Żelazny gorliwie czytelnika zachęca.

Z pewnym dystansem i krótko rozważane są natomiast poglądy wybranych myślicieli amerykańskiej psychologii egzystencjalnej: Valoma i Maya. Żelazny trochę sobie kpi (s. 525) z amerykańskiej maniery lekceważenia tzw. filozofii kontynentalnej ze względu na jej trudność określaną mianem „mętniactwa”. Ostatecznie jednak działalność amerykańskich psychologów egzystencjalnych, jako pionierów tak zwanej terapii filozoficznej ocenia bardzo wysoko.

Książka Żelaznego zawiera pierwszą $\mathrm{w}$ piśmiennictwie polskim holistyczną próbę prezentacji myśli egzystencjalnej. Przełamuje ona wynikający w dużej części z prostackiej, ideologicznej krytyki marksistowskiej stereotyp, każący traktować egzystencjalizm jako „coś niepoważnego”. Z drugiej strony umożliwia uwolnienie się od traktowania pojęcia egzystencji, jako czegoś bardzo ważnego, a tak tajemniczego, że nie jest możliwe, ani nawet potrzebne wyjaśnianie jego nazwy.

Ze względu na przystępność języka książka może być przeznaczona dla szerokiego kręgu czytelników, choć natrafiamy w niej na partie trudniejsze, dotyczące bardziej złożonych zagadnień teoriopoznawczych. Ale partie te, z których część autor zawarł w odrębnych artykułach, tak wpisują się w kompozycję całości, że nawet ich niedokładne zrozumienie nie przeszkadza niewprawnemu czytelnikowi w podążaniu za tokiem wywodu. 